\title{
Temporal and spatial evaluation of the River Nile water quality between Qena and Sohag Cities, Egypt
}

\author{
Ahmed A. Elnazer ${ }^{1}$, Alaa Mostafa ${ }^{2}$, Salman A. Salman ${ }^{1 *}$ D, Elmontser M. Seleem² and Ahmed Gab-Allah Al-Gamal ${ }^{3}$
}

\begin{abstract}
Background: The River Nile became under stress in the last decades from the different human (anthropogenic) activities. The present work dealt with the River Nile water quality from Qena to Sohag districts, Egypt. Sixty water samples were collected during 2016 winter and summer and subjected to chemical analysis according to standard methods.

Results: The results indicated temporal and spatial variations in the chemical content of the collected water samples. The samples showed higher concentrations of $\mathrm{Ca}, \mathrm{Cl}, \mathrm{Cd}, \mathrm{Cu}, \mathrm{Pb}, \mathrm{Cr}$, and $\mathrm{Zn}$ during summer than winter, owing to intensive human activities during summer such as navigation and agricultural and industrial activities. The samples enriched with $\mathrm{pH}, \mathrm{TDS}, \mathrm{Mg}, \mathrm{Na}, \mathrm{K}, \mathrm{HCO}_{3}, \mathrm{SO}_{4}$, and $\mathrm{NO}_{3}$ during winter, due to the small water column and slow flow-rate.

Conclusion: The studied samples in winter and summer were unsuitable for drinking due to the recorded unacceptable concentrations of $\mathrm{As}, \mathrm{Cd}, \mathrm{Cr}$, and $\mathrm{Pb}$ in the studied samples. The presence of $\mathrm{As}, \mathrm{Cd}, \mathrm{Cr}$, and $\mathrm{Pb}$ may impact water consumer health because the used coagulation procedures in drinking water stations are not effective in the removal of these metals. The River Nile water is suitable for irrigation, except for some samples, which contain elevated concentrations of As and Cr. Finally, the River Nile protection laws must be strictly applied by national and international authorities to save its water quality.
\end{abstract}

Keywords: River Nile, Heavy metals, Drinking water, Irrigation water, Pollution, Spatial, Temporal, Evaluation, Egypt

\section{Background}

The River Nile is the main source of fresh water in Egypt. However, it has been reported that Egypt is one of the first 10 countries that will be suffering from water scarcity by the year 2025 , due to the rapid population growth (Lawson 2011). The River Nile passes through 10 countries and gets its water from three Tributaries; the Blue Nile (68\%), Atbara (22\%) and the White Nile (10\%) (Garzanti et al. 2015). The White Nile drains Archaean-Proterozoic rocks of the Congo Craton and extends through Precambrian rocks of the Saharan Metacraton (Abdelsalam et al. 2002). The Blue Nile and Atbara, together with its tributary the Tekeze, are sourced in the Ethiopian Highlands, where they drain the flood basalts (Garzanti et al. 2015).

\footnotetext{
* Correspondence: sal_man19@yahoo.com

${ }^{1}$ Geological Sciences Department, National Research Centre, POB: 12622, 33

El Bohouth St. (former El Tahrir St.)- Dokki, Giza, Egypt

Full list of author information is available at the end of the article
}

One of the major environmental hazards worldwide is the pollution of water resources with heavy metals (HMs). HMs are present naturally in river water with very low concentrations safe for aquatic biota and come mainly from the weathering of rocks and soils. Meanwhile, the high concentrations come from the anthropogenic sources as domestic and industrial wastewater effluents and urban runoff (Reza and Singh 2010). The pollution of the aquatic environment with these metals can be poisonous and even killed the fish (Zeitoun and Mehana, 2014).

Human activities produce a huge amount of wastewater that can reach water bodies causing the deterioration of water quality and hence causing adverse human health impact (Melegy et al. 2014; Mohanta and Goel 2014). The River Nile receives a huge amount $\left(\approx 549 \times 10^{6} \mathrm{~m}^{3}\right.$ year $\left.^{-1}\right)$ of industrial effluents (El-Sheekh 2009). These effluents are loaded with different pollutant types, which can adversely impact the River Nile quality. The area contains many pollution point sources as agricultural drains, agro-industries, metallurgical (Aluminum) industries, navigation, and 
drinking water network washing station. Several authors (Ali et al., 2011; Melegy et al. 2014; Zaki et al. 2015, and Abu El Ella et al., 2017) pointed out the adverse impact of sugarcane industries on the River Nile water quality. Ipeaiyeda et al. (2012) concluded that the smelting activities in aluminum production led to the pollution of Essene Creek, Imo and Utaewa Rivers.

In the study area, coal is used in smelters that represent a major source of environmental pollution with HMs. On the other hand, the natural sources of pollution are the drains of the watersheds in the upstream and the Eastern Desert rocks during the seasonal flash floods. Also, the study area contains huge canal/drain networks. These networks facilitate the dispersal of pollutants into the river. The irrigation system in this region is by surface irrigation; therefore, the excess water containing these organic and/or inorganic chemical compounds migrates to the drains by infiltration or seepage. The aims of this work were the determination of the River Nile water quality and spatial as well as temporal variation in its inorganic chemical contents between Qena and Sohag districts.

\section{Methods}

Water samples were collected from 30 sampling points along the River Nile Trunk along a distance of about $150 \mathrm{~km}$ from Qena to Sohag districts (Fig. 1) in 1-L plastic bottles for physicochemical tests during winter 2016 . The same sites were sampled again during summer 2016. A well-constrained Global Positioning System (GPS) was used for navigation to locate the sampling sites accurately. The samples were transferred to the Geological Sciences Department, National Research Centre (NRC), for analyses. The temperature, $\mathrm{pH}$, and total dissolved solids (TDS) were determined in situ with digital HANNA pH meter (HI 991300), which was

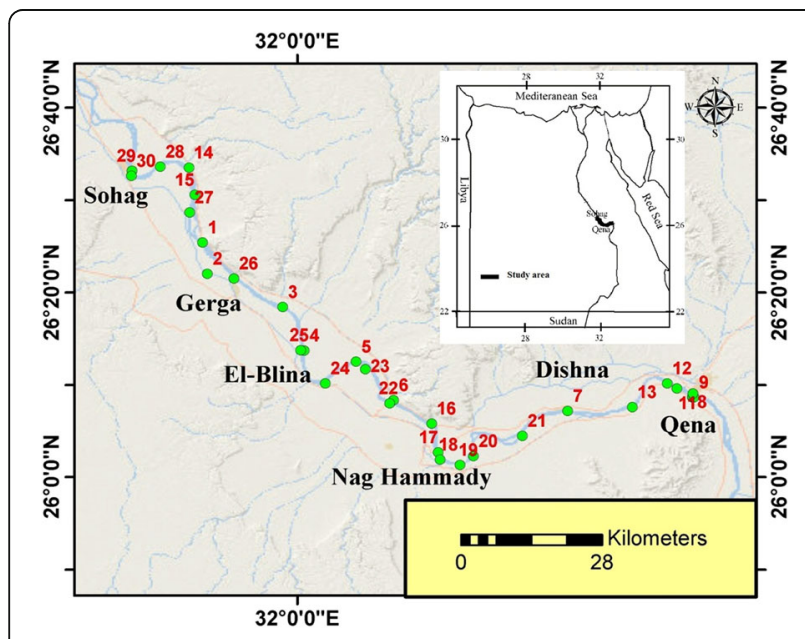

Fig. 1 Location map of the study area and sampling Sites calibrated prior to taking readings. In the laboratory, the samples were filtered and analyzed for chemical constituents by using standard procedures of APHA (1995). Calcium, magnesium, carbonate, bicarbonate and chloride were analyzed by volumetric methods. Sodium and potassium were determined by flame photometer. $\mathrm{Ni}$ trate and sulphate were determined by using HANNA Spectrophotometer instrument (model HI 83215). HMs were determined by using the atomic absorption spectroscopy (Perkin Elmer 400). The suitability of water for irrigation was determined by calculating the sodium absorption ratio (SAR) according to Richards (1954) equation (All values in $\mathrm{meq} / \mathrm{l})$ :

$$
\mathrm{SAR}=\mathrm{Na}^{+} /\left[\left(\mathrm{Ca}^{2+}+\mathrm{Mg}^{2+}\right) / 2\right]^{1 / 2}
$$

\section{Results}

The measured parameters' descriptive statistics of the River Nile water for both winter and summer seasons are illustrated in Tables 1 and 2 and Figs. 2 and 3. Carbonate was not detected in the studied samples. Nearly all the collected samples contain acceptable levels of water major characteristics (Table 1) for drinking and irrigation purposes. It was observed that water samples contain higher concentrations of the studied parameters (except $\mathrm{Ca}$ and $\mathrm{Cl}$ ) during winter over than summer. On contrary, samples collected during summer contained higher concentrations of $\mathrm{Pb}, \mathrm{Cr}, \mathrm{Cu}, \mathrm{Cd}, \mathrm{As}$, and $\mathrm{Zn}$ than the samples collected during the winter season (Table 2).

\section{Discussion}

\section{Water chemical characteristics}

The recorded slightly alkaline $\mathrm{pH}$ is preferable in waters for the removal of heavy metals by precipitation as carbonate or bicarbonate (Ahipathy and Puttaiah 2006). The $\mathrm{pH}$ was relatively high in winter, because the water stays longer in contact with bottom sediment owing to the low flow rate and shallow water column. With respect to TDS, the water samples are considered good potable water with values $<500 \mathrm{ppm}$. A higher level of TDS during the winter season can be attributed to untreated agricultural and domestic wastes discharged into the river, as well as water longer contact with bottom sediment. Samples (23) and (24) were collected near agricultural drains while the sample (26) at Gerga Sugar factory. The water longer contact with bottom sediment was the main reason in the elevated concentrations of $\mathrm{Mg}, \mathrm{Na}, \mathrm{K}, \mathrm{HCO}_{3}, \mathrm{SO}_{4}$, and $\mathrm{NO}_{3}$ during winter than summer. The appearance of $\mathrm{NO}_{3}$ in concentrations $>5 \mathrm{ppm}$ is reflecting unsanitary conditions (Uqab et al. 2017) in the Nile water.

With respect to the studied $\mathrm{HMs}$, Pb was the most dominant among all the metals studied in the collected water samples at different stations. The noticed low $\mathrm{Pb}$ 
Table 1 Descriptive statistics of the measured major characteristics of water sample

\begin{tabular}{|c|c|c|c|c|c|c|c|c|c|}
\hline Parameter & Season & Min & Max & Mean & Q1 & Q2 & Q3 & MAL & Passed \% \\
\hline \multirow[t]{2}{*}{$\mathrm{pH}$} & S & 7.43 & 8.05 & $7.78 \pm 0.19$ & 7.6 & 7.84 & 7.97 & $6.5-8.5$ & 100 \\
\hline & W & 7.70 & 8.68 & $8.41 \pm 0.23$ & 8.39 & 8.45 & 8.54 & & 96.6 \\
\hline \multirow[t]{2}{*}{ TDS } & S & 130 & 270 & $148.7 \pm 24.2$ & 140 & 140 & 150 & 1000 & 100 \\
\hline & W & 128.8 & 409.9 & $208.9 \pm 53$ & 187.4 & 199.1 & 207.9 & & 100 \\
\hline \multirow[t]{2}{*}{$\mathrm{Ca}$} & S & 24.9 & 45.7 & $31.1 \pm 4.2$ & 28.6 & 30.5 & 32.4 & 75 & 100 \\
\hline & W & 18.4 & 59.6 & $28.6 \pm 7.2$ & 25.6 & 26.6 & 30.7 & & 100 \\
\hline \multirow[t]{2}{*}{$\mathrm{Mg}$} & S & 18.5 & 38.5 & $24.4 \pm 4.1$ & 21.6 & 23.1 & 26.3 & 100 & 100 \\
\hline & W & 18.7 & 52.6 & $27.8 \pm 7.7$ & 22.1 & 27.5 & 31.6 & & 100 \\
\hline \multirow[t]{2}{*}{$\mathrm{Na}$} & S & 14.4 & 26.1 & $16 \pm 2.1$ & 15 & 15.6 & 15.6 & 250 & 100 \\
\hline & W & 22.1 & 99.5 & $30.3 \pm 13.8$ & 25.4 & 27 & 29.4 & & 100 \\
\hline \multirow[t]{2}{*}{ K } & S & 1.4 & 6.22 & $3.7 \pm 1$ & 3.01 & 3.8 & 3.82 & 12 & 100 \\
\hline & W & 3.5 & 6.9 & $4.4 \pm 0.6$ & 4.2 & 4.4 & 4.5 & & 100 \\
\hline \multirow[t]{2}{*}{$\mathrm{Cl}$} & S & 28 & 57.2 & $43.7 \pm 7.1$ & 40 & 44 & 47.9 & 250 & 100 \\
\hline & W & 8.1 & 43.5 & $18.5 \pm 8.9$ & 12.1 & 16.2 & 23.2 & & 100 \\
\hline \multirow[t]{2}{*}{$\mathrm{HCO}_{3}$} & S & 122 & 274.5 & $157.7 \pm 24.8$ & 148.8 & 154.6 & 159.3 & $300^{*}$ & 100 \\
\hline & W & 166.4 & 517.4 & $263.5 \pm 77.2$ & 215.9 & 256.9 & 285.5 & & 87 \\
\hline \multirow[t]{2}{*}{$\mathrm{SO}_{4}$} & S & 5 & 31.3 & $16.5 \pm 7.3$ & 10 & 15.6 & 20.6 & 250 & 100 \\
\hline & W & 15 & 50 & $20.4 \pm 6.4$ & 18 & 20 & 20 & & 100 \\
\hline \multirow[t]{2}{*}{$\mathrm{NO}_{3}$} & S & 0 & 6.6 & $1.1 \pm 1.5$ & 0 & 0.5 & 1.5 & 50 & 100 \\
\hline & W & 0.3 & 23.8 & $8.4 \pm 5.7$ & 3.9 & 6.3 & 12.9 & & 100 \\
\hline \multirow[t]{2}{*}{ SAR } & S & 0.45 & 0.69 & $0.52 \pm 0.05$ & 0.5 & 0.51 & 0.54 & $10^{* *}$ & 100 \\
\hline & W & 0.78 & 2.52 & $0.96 \pm 0.31$ & 0.84 & 0.9 & 0.94 & & 100 \\
\hline
\end{tabular}

W winter, S summer, Min minimum, Max Maximum, MAL maximum allowable concentration for drinking (WHO 2011)

Q1: 1 st quartile ( $25 \%$ of samples); Q2: 2 nd quartile ( $50 \%$ of samples); Q3: 3rd quartile (75\% of samples). Passed \%: the percent of samples acceptable for drinking * $\mathrm{HCO}_{3}$ acceptable value (in Zidi et al. 2017)

**SAR acceptable value (after Richards 1954)

Table 2 Descriptive statistics of the measured heavy metals $(\mu \mathrm{g} / \mathrm{l})$ in comparison with drinking and irrigation standards

\begin{tabular}{|c|c|c|c|c|c|c|c|c|c|c|c|}
\hline Parameter & Season & Min & Max & Mean & Q1 & Q2 & Q3 & $\mathrm{MAL}^{1}$ & Pass $^{1} \%$ & $\mathrm{MAL}^{2}$ & $\operatorname{Pass}^{2} \%$ \\
\hline \multirow[t]{2}{*}{$\mathrm{Pb}$} & W & 163 & 202 & $183 \pm 9.4$ & 175 & 182 & 189 & 10 & 0 & 5000 & 100 \\
\hline & S & 193 & 402 & $287.9 \pm 57.3$ & 239 & 289.5 & 332 & & 0 & & 100 \\
\hline \multirow[t]{2}{*}{$\mathrm{Cr}$} & W & 1.7 & 62.9 & $23.1 \pm 13.8$ & 15.3 & 19.6 & 30.6 & 50 & 93.3 & 100 & 100 \\
\hline & S & 63 & 467 & $288.2 \pm 97$ & 224.8 & 307.0 & 349 & & 0 & & 3.3 \\
\hline \multirow[t]{2}{*}{$\mathrm{Cu}$} & W & bdl & 110 & $31.7 \pm 34.1$ & 0 & 25.0 & 50 & 2000 & 100 & 200 & 100 \\
\hline & S & bdl & 170 & $40.7 \pm 54.6$ & 0 & 0 & 70 & & 100 & & 100 \\
\hline \multirow[t]{2}{*}{$\mathrm{Cd}$} & W & bdl & 4 & $2.0 \pm 1.1$ & 1.3 & 2.0 & 3 & 3 & 93.3 & 10 & 100 \\
\hline & S & 1 & 5 & $3.1 \pm 1.0$ & 2.3 & 3.0 & 4 & & 70 & & 100 \\
\hline \multirow[t]{2}{*}{ As } & W & bdl & 3086 & $322.6 \pm 698.3$ & 0 & 0 & 228 & 10 & 63.3 & 100 & 70 \\
\hline & S & bdl & 2380 & $375.4 \pm 653.6$ & 0 & 0 & 356 & & 63.3 & & 66.7 \\
\hline \multirow[t]{2}{*}{$\mathrm{Zn}$} & W & 50 & 280 & $136.3 \pm 48.4$ & 102.5 & 130.0 & 160 & 3000 & 100 & 2000 & 100 \\
\hline & S & 60 & 700 & $218 \pm 149.5$ & 140 & 170.0 & 220 & & 100 & & 100 \\
\hline
\end{tabular}



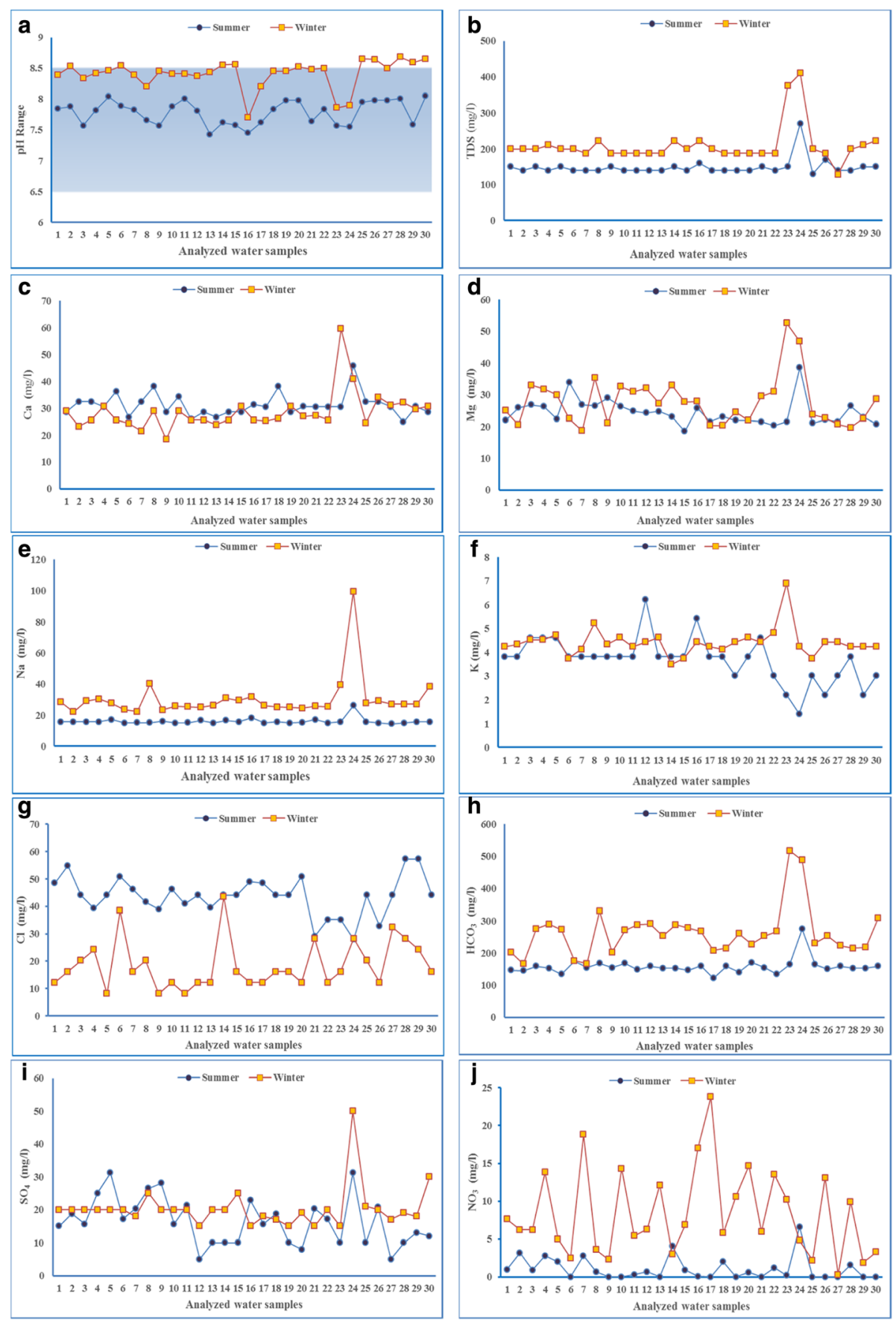

Fig. 2 Spatial and temporal variation in a pH, b TDS, c Ca, d $\mathrm{Mg}$, e $\mathrm{Na}, \mathbf{f ~} \mathrm{K}, \mathbf{g ~ C l}, \mathbf{h} \mathrm{HCO}_{3}$, i $\mathrm{SO}_{4}$, and $\mathbf{j} \mathrm{NO}_{3}$

concentration during the winter season compared to the summer season (Fig. 3a) may result from the human activities during summer such as navigation, traffic, wastewater effluents, and urban runoff. The spill of fuel and traffic exhaust can produce a considerable concentration of $\mathrm{Pb}$ (Elnazer et al. 2015). The $\mathrm{Pb}$ was detected as a pollutant for the River Nile from several decades, where $24 \mu \mathrm{g} / \mathrm{l}$ was recorded in 1987 (Lasheen 1987) and about
$214.3 \mu \mathrm{g} / \mathrm{l}$ in 2009 (Toufeek 2011). Narrow ranges of Cd (bdl-4 and 1-5 $\mu \mathrm{g} / \mathrm{l}$ in winter and summer, respectively) were recorded in the studied samples with noticed higher concentrations during summer than winter (Table 2, Fig. 3d). The higher concentration of $\mathrm{Cd}$ in the summer season might have resulted from the sediments of Lake Nasser, which contains about $0.175 \mu \mathrm{g} / \mathrm{g}$ of $\mathrm{Cd}$ (Goher et al. 2014). Also, navigation, agricultural runoff, 

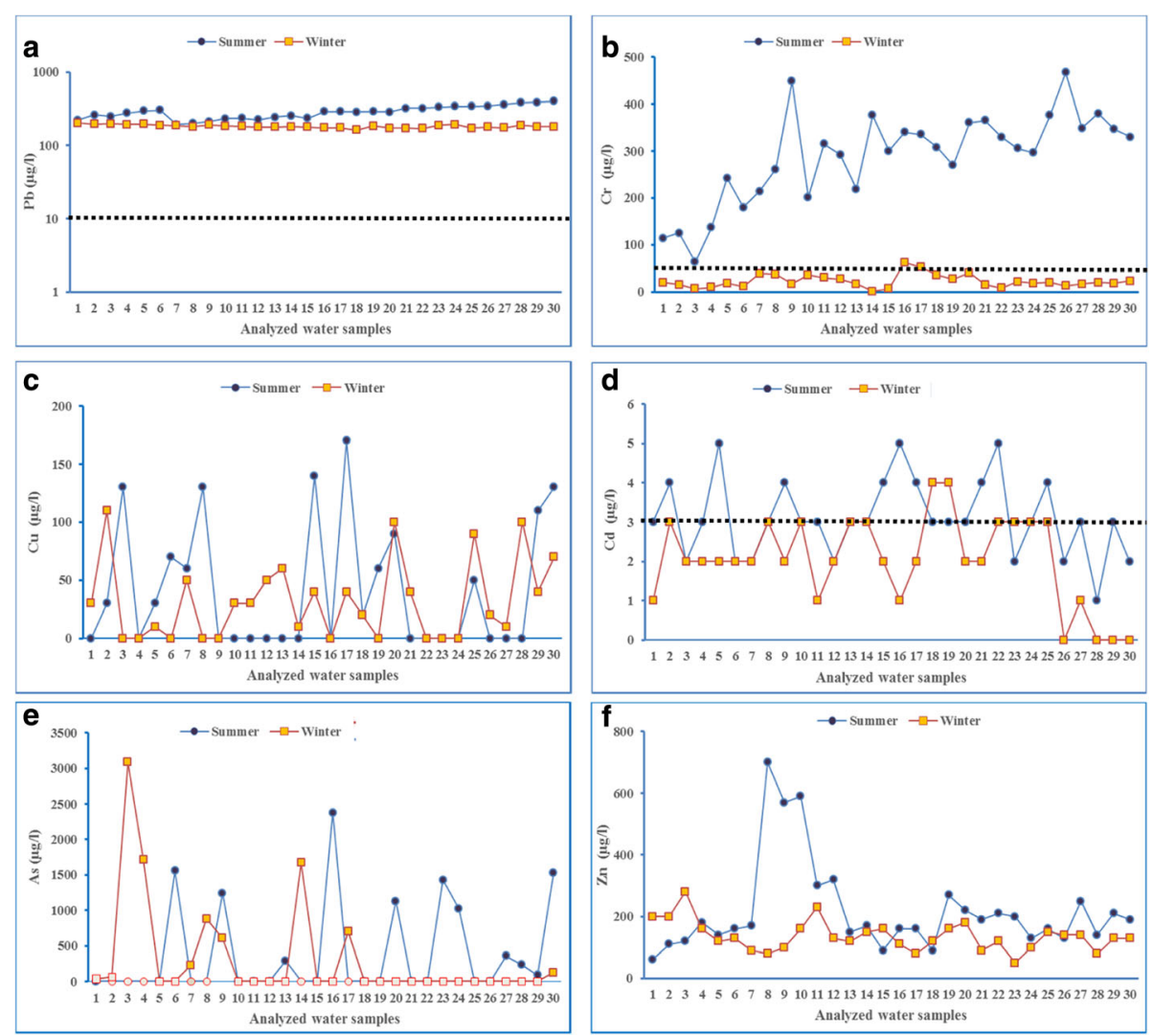

Fig. 3 Spatial and temporal variation in a Pb, b Cr, c Cu, d Cd, e As, and $\mathbf{f}$ Zn concentrations (dashed line= allowable limits according to WHO 2011)

and sewage effluents discharge to the water courses contributed to the $\mathrm{Cd}$ load in this season.

Arsenic was detected only in about $36.7 \%$ of the studied samples. These results support the anthropogenic source of As in the study area water. The highest concentrations were recorded in Qena city (samples 8, 9, and 10), in agricultural drains (samples 14, 24, and 30), and at navigation sites (samples 4 and 20). The increase of As during summer than winter (Fig. 3e) might be due to the high and intensive activities during summer than winter such as navigation. The marked variation in As concentrations proposed intermixed sources in the study area including, to great extent, the role of human activities and to a limited extent the role of the natural process, especially the occasionally storms, which carry considerable amounts of sediments from the Eastern Desert mountains, where some rocks in the Eastern Desert contain up to $75 \mathrm{mg} / \mathrm{kg}$ of As (Sadek et al. 2015).

The mostly affected metal with seasonal variation was $\mathrm{Cr}$; its concentration (Table 2) during summer $(288.2 \mu \mathrm{g} / \mathrm{l})$ was 12 times its concentration during winter $(23.1 \mu \mathrm{g} / \mathrm{l})$. The observed higher concentration of $\mathrm{Cr}$ during summer was mainly carried from the Ethiopian lands with water as a result of the dissolution of ferromagnesian minerals by rains in the Ethiopian mafic/ ultramafic rocks (Omer, 1996). Copper was not detectable in $>50 \%$ of the samples collected during summer and $30 \%$ of the samples collected during winter. The reports show that sites with a low concentration of $\mathrm{Cu}$ had high $\mathrm{Ca}$ levels (Suresh 2008); this is supported by the negative correlation between $\mathrm{Ca}$ and $\mathrm{Cu}$ during the current study (Fig. 4) as a result of ion-exchange. The absence of $\mathrm{Cu}$ from about $50 \%$ of the studied samples during summer could be attributed to the high flow rate and volume of water, which led to the low interaction between sediments and water.

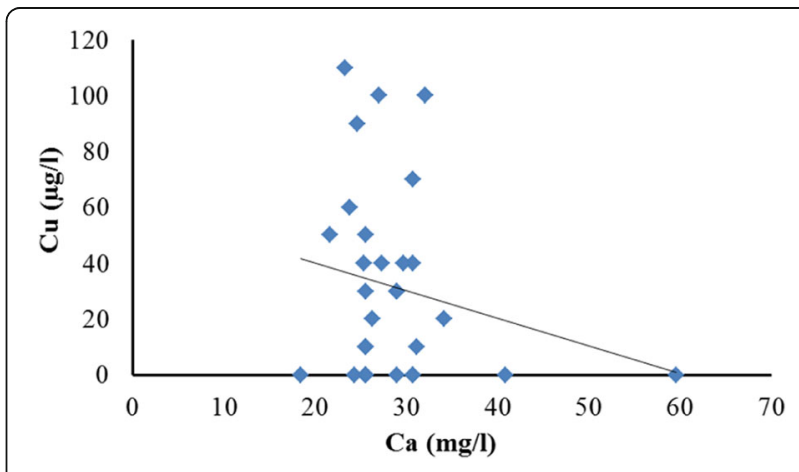

Fig. 4 Relationship between Ca and Cu during winter 
The recorded low concentrations of $\mathrm{Zn}$ can be attributed to its absorbance by bottom sediment (Singh 2005, Kabata-Pendias and Mukherjee 2007). The higher Zn concentration in summer than winter (Fig. 4f) might result from the small water column and slow flow-rate during winter, where $\mathrm{Zn}$ is mainly absorbed on the mineral grains. Also, lower $\mathrm{pH}$ values during summer than winter enhance the solubility of $\mathrm{Zn}$ (Singh 2005). Other sources of $\mathrm{Zn}$ into aquatic ecosystems include urban runoff, fertilizers, and municipal sewage (Kabata-Pendias and Mukherjee 2007, Damodharan 2013). Generally, the variation in the concentrations of the studied elements from site to another is mostly related to human activities (industrial, agricultural, urban runoff, traffic, etc.), which differentiate from location to another and also from winter to summer.

\section{Evaluation of water for drinking}

The results indicated the suitability of water for drinking purposes with respect to $\mathrm{pH}$, TDS, $\mathrm{Ca}, \mathrm{Mg}, \mathrm{Na}, \mathrm{HCO}_{3}$, $\mathrm{SO}_{4}, \mathrm{Cl}, \mathrm{NO}_{3}, \mathrm{Cu}$, and $\mathrm{Zn}$ was within the permissible limits of WHO (2011) during the two seasons (Tables 1 and 2). Also, most of the studied samples contain acceptable levels of As (19 samples in winter and 19 samples in summer), $\mathrm{Cd}$ (28 samples in winter and 21 samples in summer), and $\mathrm{Cr}$ (28 samples in winter). On the other hand, the water samples contained unacceptable concentrations $\mathrm{Pb}$ (during winter and summer) and $\mathrm{Cr}$ (during summer).

The presence of the unacceptable concentrations of some metals in the River Nile water might cause health problems, because in Egypt, there are two types of water treatment plants (conventional and compact). The main step in the two types is the use of alum as a coagulant (Donia 2007). Unfortunately, the use of alum as coagulant had led to the appearance of high $\mathrm{Al}$ (the major component value in alum) concentrations in the domestic tap water (DWAF 1996). The presence of $\mathrm{Al}$ in water may cause Alzheimer's disease and carcinogenic effects. In addition, the percentage removal of the metals from raw water samples increased with $\mathrm{mg} / \mathrm{l}$ dosage of coagulant. The efficiency of removal for $\mathrm{As}, \mathrm{Cd}, \mathrm{Cr}, \mathrm{Cu}, \mathrm{Mn}$, $\mathrm{Ni}$, and $\mathrm{Zn}$ was $3.7,5.88,85.42,4.63$, and $47.37 \%$, respectively, at $10 \mathrm{mg} / \mathrm{l}$ dose of $\mathrm{Al}_{2}\left(\mathrm{SO}_{4}\right)_{3}$ (Fatoki and Ogunfowokan 2002). This indicates that till after treatment process toxic levels of metals may reach the end consumers of water causing many health problems. Therefore, more attention should be given to the presence and sources of these elements in drinking water by the governmental authorities.

\section{Evaluation of water for irrigation}

All the samples collected during this study had TDS $<500 \mathrm{ppm}$ and considered excellent for irrigation without any detrimental effect according to Richards (1954). Also, all the samples collected during this study had SAR $<10$ (Table 1) and can be used safely for all types of soil based on Richards (1954) classification of SAR. In addition, the studied water samples contain acceptable concentrations of the studied metals, except the recorded As (during winter and summer) and $\mathrm{Cr}$ (during summer only) in comparison with NAS-NAE (1972) allowable levels of HMs.

\section{Conclusion}

The River Nile water is fresh water with TDS $<500$ ppm, with acceptable concentrations of the different ions. The main problem comes from the pollution of water mainly with $\mathrm{Pb}$ and to some extents with $\mathrm{Cd}, \mathrm{Cr}$, and As. The increased human activities during summer season had led to the increase of $\mathrm{Ca}, \mathrm{Cl}, \mathrm{Cd}, \mathrm{Cu}, \mathrm{Pb}, \mathrm{Cr}$, and $\mathrm{Zn}$ concentrations than the winter season. On the other hand, the slow flow rate and shallow water column during winter were caused the increase in the concentrations of $\mathrm{pH}$, TDS, $\mathrm{Mg}, \mathrm{Na}, \mathrm{K}, \mathrm{HCO}_{3}, \mathrm{SO}_{4}$, and $\mathrm{NO}_{3}$.

\section{Acknowledgements}

The authors would like to thank the Geological Sciences Dept., National Research Centre, and Geology Dept. Al-Azhar Univ. (Assiut Branch) for their facilitates during this work.

\section{Authors' contributions \\ All authors contributed equally in all article steps. All authors read and approved the final manuscript.}

\section{Ethics approval and consent to participate Accepted}

Consent for publication

Accepted

Competing interests

The authors declare that they have no competing interests.

\section{Publisher's Note}

Springer Nature remains neutral with regard to jurisdictional claims in published maps and institutional affiliations.

\section{Author details}

${ }^{1}$ Geological Sciences Department, National Research Centre, POB: 12622, 33 El Bohouth St. (former El Tahrir St.)- Dokki, Giza, Egypt. 'Geology Department, Faculty of Science, Al Azhar University, Assuit Branch, Cairo, Egypt. ${ }^{3}$ Quarries Administration, Sohag, Sohag Governorate, Egypt.

Received: 9 June 2018 Accepted: 8 August 2018

Published online: 03 September 2018

\footnotetext{
References

Abdelsalam MG, Liégeois JP, Stern RJ (2002) The Saharan Metacraton. J Afr Earth Sci 34:119-136

Abu El Ella EM, Elnazer AA, Salman SA (2017) The effect of human activities on the pollution of water in Southwest Giza area, Egypt. Water Sci Technol Water Supply 17(5):1368-1376

Ahipathy MV, Puttaiah ET (2006) Ecological characteristics of Vrishabhavathy River in Bangalore (INDIA). Environ Geol 49(8):1217-1222

Ali SM, Sabae SZ, Fayez M, Monib M, Hegazi NA (2011) The influence of agroindustrial effluents on River Nile pollution. J Adv Res 2:85-95

APHA (1995) Standard methods for the examination of water and wastewater $\left(19^{\text {th }}\right.$ ed). American Public Health Association, Washington, DC
} 
Damodharan U (2013) Bioaccumulation of heavy metal in contaminated river Water - Uppanar, Cuddalore South East coast of India. In: Dar IA (ed) Perspectives in Water Pollution. IntechOpen, pp 23-34 doi.org/10.5772/53374 Donia N. Survey of Potable Water Quality Problems in Egypt. The $11^{\text {th }}$ Intern. Water Tech. Conf., 15-18 March, IWTC11 Sharm El-Sheikh, Egypt, 2007: 1049-1058

DWAF (1996) South Africa water quality guidelines for domestic uses ( $2^{\text {nd }}$ edn.). Department of Water Affairs and Forestry, Pretoria

Elnazer AA, Salman SA, Seleem EM, Abu El Ella EM (2015) Assessment of some heavy metals pollution and bioavailability in roadside soil of AlexandriaMarsa Matruh highway, Egypt. Intern. J. Ecol Article ID 689420:7. https://doi. org/10.1155/2015/689420

El-Sheekh M (2009) River Nile pollutants and their effect on life forms and water quality. In: Dumont HJ (ed) The Nile: origin, environments, limnology and human use. Series: Monographiae Biologicae 89. Springer, Dordrecht, pp 395-406

Fatoki OS, Ogunfowokan AO (2002) Effect of coagulant treatment on the metal composition of raw water. Water SA 28(3):293-297

Garzanti E, Ando S, Padoan M, Vezzoli G, El Kammar A (2015) The modern Nile sediment system: processes and products. Quaternary Sci Rev 130:9-56

Goher ME, Farhat HI, Abdo MH, Salem SG (2014) Metal pollution assessment in the surface sediment of Lake Nasser, Egypt. Egypt J Aquat Res 40:213-224

Ipeaiyeda AR, Umo NS, Okojevoh GE (2012) Environmental pollution induced by an aluminium smelting plant in Nigeria. Global J Sci Frontier Res Chem 12(1):59-71

Kabata-Pendias A, Mukherjee AB (2007) Trace elements from soil to human. Springer Berlin Heidelberg New York, p 550

Lasheen R (1987) The distribution of trace metals in Aswan High Dam Reservoir and River Nile ecosystem. In: Hutchinson TC, Means KM (eds) Lead, mercury, cadmium and arsenic in the environment, SCOPE. John wily and Itd, pp 235-354

Lawson EO (2011) Physico-chemical parameters and heavy metal contents of water from the mangrove swamps of Lagos Lagoon, Lagos, Nigeria. Adv Biolo Res 5:8-21

Melegy AA, Shaban AM, Hassaan MM, Salman SA (2014) Geochemical mobilization of some heavy metals in water resources and their impact on human health in Sohag governorate, Egypt. Arab J of Geosci 7:4541-4552

Mohanta T, Goel S (2014) Assessment of water quality of three different aquatic environments over three seasons. 1st Inter. Congress Environ., Biotechnology Chemistry Eng. IPCBEE 64(10):49-53

NAS-NAE (National Academy of Science and National Academy of Engineering) (1972) Water quality criteria. Report prepared by committee of water quality on request of U.S. Environmental Protection Agency, Washington, D.C., USA, p 594

Omer AAM. Geological, mineralogical and geochemical studies on the Neogene and Quaternary Nile basin deposits, Qena- Assiut stretch, Egypt. Ph.D. Thesis, Geol. Dept., Fac. Sci., South Valley Univ 1996

Reza R, Singh G (2010) Heavy metal contamination and it indexing approach for river water. Inter J Environ Sci Tech 7:785-792

Richards LA (1954) Diagnosis and improvement of saline and alkali soils, USDA Agric. Handb. 60. USDA, Washington, DC

Sadek MF, Ali-Bik MW, Hassan SM (2015) Late Neoproterozoic basement rocks of Kadabora-Suwayqat area, Central Eastern Desert, Egypt: geochemical and remote sensing characterization. Arab J Geosci 8:10459-10479

Singh VP (2005) Toxic metals and environmental issues. Sarup and Sons, New Delhi, p 362

Suresh CR (2008) Monitoring metal containing particulates distribution on college campus using dandelion (Taraxacum offinale) leaves as receptors, $\mathrm{M}$. Sc. Thesis, the faculty of the Department of Chemistry, East Tennessee State University, p 125

Toufeek MEF (2011) Distribution of cadmium and lead in Aswan Reservoir and River Nile water at Aswan. World App Sci J 13(2):369-375

Uqab B, Singh A, Mudasir S (2017) Impact of sewage on physico-chemical water quality of Tawi River in Jammu city. Environ. Risk Assess Remediat 1(2):56-61

WHO (World Health Organization) (2011) Guideline for drinking water quality. Recommendations, 4th edn. World Health Organization, Geneva

Zaki R, Ismail EA, Mohamed WS, Ali AK (2015) Impact of surface water and groundwater pollutions on irrigated soil, El Minia Province, Northern Upper Egypt. J Water Reso Protec 7:1467-1472

Zeitoun MM, Mehana EE (2014) Impact of water pollution with heavy metals on fish health: overview and updates. Global Veterinaria 12(2):219-231

Zidi C, Jamrah A, Al-Issai L (2017) Assessment of groundwater quality in AlBuraimi, Sultanate of Oman. J Mater Environ Sci 8(4):1266-1276

\section{Submit your manuscript to a SpringerOpen ${ }^{\odot}$ journal and benefit from:}

- Convenient online submission

- Rigorous peer review

- Open access: articles freely available online

High visibility within the field

- Retaining the copyright to your article

Submit your next manuscript at $\boldsymbol{\sim}$ springeropen.com 